\title{
KÖZÉPISKOLÁSOK EREDMÉNYESSÉGE
}

\author{
Pilot kutatás Hargita megyében
}

TÓDOR IMRE

Debreceni Egyetem, Bölcsészettudományi Kar

Kutatásunk célja a felekezeti és a nem felekezeti középiskolába jelentkező tanulók iskolai eredményességének vizsgálata szektorközi megvilágításban, Hargita megyében. Kutatási kérdésünk úgy szól: vajon a legeredményesebb iskola egyben a „legjobb” iskola is? Kérdéseinkre a 9. és a 11. osztályos felekezeti és a hozzárendelt nem felekezeti iskolás tanulók körében lekérdezett 1064 elemszámú vizsgálat adatainak elemzésével kerestünk választ. Kutatásunkban az eredményesség objektív (kvantitatív) dimenziója mellett a szubjektív (kvalitatív) dimenziót is mértük, amelyet olyan magyarázó változókkal vetettünk össze, mint a tanuló családi hátterének hatása és a tanulói összetétel.

Kulcsszavakः eredményesség dimenziói, családi háttérhatás, szektorközi kutatás

The objective of my research is the investigation of the learning efficiency of students applying for both denominational and non-denominational high schools in a cross-sectoral perspective in Harghita County. The main question of the research is whether the most efficient school is "the best" school at the same time. The answer to this can be found with the help of an analysis of the survey data collected from 1064 students from the 9th and 11th grades in denominational schools as well as non-denominational schools allocated to them. In the study, besides the objective (quantitative) dimension of efficiency, I also measured the subjective (qualitative) dimension, which was then compared to explanatory variables such as the impact of the student's family background, the student population.

Keywords: dimension of efficiency, impact of family background, cross-sectoral research

\section{Bevezetés}

$\mathrm{R}$ omániában, ahogyan Magyarországon is, évente közzéteszik a középiskolák rangsorát, amely alapján a tanintézményeket, az oktatás közvetlen és közvetett felhasználói a ,jó” és a „rossz”, az „erős” és a „gyenge”, az „eredményes” és az „eredménytelen" stb. jelzőkkel látják el. Így felmerül a kérdés, hogy milyen mutatók, milyen összefüggések alapján titulálható egy iskola eredményesnek? Romániában a rangsort a következő mutatók alapján képzik: 1. az iskola tanulóinak középiskolai felvételi átlag-

Levelező szerző: Tódor Imre, RO-537297, Csíkcsicsó 605, Hargita megye, Románia.

E-mail: imretodor@gmail.com 
eredménye (40\%), 2. az iskola tanulóinak érettségi átlageredménye (30\%), 3. az iskola tanulóinak sikeres érettségije (20\%), 4. a tanulmányi tantárgyversenyeken elért eredmények (10\%). E változók a kognitív eredményességről szólnak, azok is az iskolai és a családi háttérhatástól független módon. Ugyanakkor köztudott tény, hogy az iskola feladata nemcsak a tanuló kognitív fejlesztésére, hanem ugyanolyan mértékben az affektív-érzelmi, valamint axiológiai és magatartásbeli nevelésére, szocializációjára is kiterjed. Felmerül a kérdés, hogy vajon a "legjobb” iskola egyben a "legeredményesebb” is? Mit is fed az eredményesség oktatásszociológiai fogalma? Az iskolai eredményesség egy többdimenziós terület, a bemeneti-kimeneti oldalán kívül a két időszak közti folyamatot is érdemes vizsgálni (vö. Balázsi 2016; Lannert 2004 stb.).

Keresztmetszeti kutatásról lévén szó, nem áll módunkban a be- és kimeneti időszak közt zajló folyamatot vizsgálni. Adataink alapján csak a bemeneti eredményességet tudjuk mérni, amely a tágabb kutatási témánk - tanulók középiskola-választási mechanizmusai - keretei közé nagyon jól inkadrálódik. Kutatásunkban az objektív (kvantitatív) eredményesség mellett a szubjektív (kvalitatív) eredményesség mérését is elvégezzük, majd arra vagyunk kíváncsiak, hogy mely magyarázó változók vannak rá hatással (Pusztai 2004; Bacskai 2015; Szemerszki 2015; Széll 2015 stb.).

\section{Módszerek}

Kutatásunk célcsoportját a Hargita megyei felekezeti és a hozzá illesztett nem felekezeti 9. és 11. osztályos tanulói (ISCED 3) alkotják. Azért végeztük a felmérést a kilencedikes és a tizenegyedikes diákokkal, mert ők képezik a középiskola alsó és felső szakaszába való belépést. Romániában a tanulók 8. osztály után kezdik meg középiskolai tanulmányaikat, amelynek alsó közép szintjét a kötelező szakasz (9-10. osztályok), majd a felső középfokát a 11-12. osztályok képezik.

Többlépcsős mintavételt alkalmaztunk. Az első lépcsőben a megyében fellelhető felekezeti iskolák mind bekerültek, s ehhez nem felekezeti iskolapárokat választottunk. ${ }^{1}$ Igy összesen nyolc iskola került kiválasztásra: négy felekezeti (két római katolikus, egy református és egy unitárius iskola) és négy nem felekezeti. A mintavétel második lépcsőjében az iskolákon belül a tanulók kiválasztását hajtottuk végre. A 9. és a 11. osztályos évfolyamok tanulói körében teljes körü kérdőíves lekérdezést végeztünk. Az alapsokaság 1205 fó, a válaszadók száma pedig 1064 fö volt, így a célcsoport 88,29\%-át sikerült elérnünk, a lekérdezésre 2018. április 16. - 2018. május 16. között került sor. A nem felekezeti iskolák kiválasztását és felekezetihez történő hozzáillesztését úgy végeztük el, hogy a székhely településtípusa és tanulótársadalmuk társadalmi helyzetére vonatkozó mutatók hasonlóak legyenek (vö. Pusztai 2009).

\section{Eredmények \\ Objektív (kvantitativ) típusú eredményesség}

Mivel a tanulók iskolaválasztásának konstellációjában vizsgáljuk a tanulók bemeneti eredményességét, így - a szakirodalom olvasata alapján - az első mutatót a 8. osztály

1 A megyében összesen négy településen található felekezeti iskola: három városban, és egy vidéken. 
végén levő egységes országos mérés eredményei képezték. A tanulóknak román nyelv, anyanyelv és matematika tantárgyakból kell írásbeli vizsgát tenniük, melynek osztályzata 1-10-ig terjedő skálán mozog. A három vizsgatantárgy eredményei közti korreláció erős és pozitív irányú: román nyelv és anyanyelv $(r=0,625)$, román nyelv és matematika $(r=0,681)$, anyanyelv és matematika $(r=0,622)$. Az objektív eredményességindex másik mutatóját az általános iskolai (5-8. osztályok) tanulmányi eredményeinek átlagai képezték, melynek osztályzata szintén az 1-10-ig terjedő skálán mozog. A változók közötti korreláció itt is igen erős és pozitív $(r=0,799)$, így azok egyazon indexbe tömöríthetőek. A harmadik mutatóban az első félévi érettségi és a félévi dolgozat (kötelező és választottak) tantárgyainak átlagai szerepelnek. Az általunk bevont tantárgyak közül a legalacsonyabb átlagosztályzat a fizika $(6,91)$ és a matematika $(7,43)$ tantárgyak esetében fordult elö, szektorközi összehasonlításban pedig szignifikáns eltérést találtunk: fizika 6,80 (nem felekezeti) és 7,16 (felekezeti); a matematika 7,81 (nem felekezeti) és 7,56 (felekezeti). Tehát a felekezeti tanulók esetében szignifikánsan a fizika tantárgy átlagosztályzatai a magasabbak, míg a nem felekezeti tanulók esetében a matematika tantárgyak átlagai. A tantárgyak között is erős, valamint közepes pozitív kapcsolatot találtunk, melyeket egy indexbe tömörítve elemezhetünk a továbbiak során.

A szakirodalom szerint (Szemerszki 2015; Morvai 2018; Horn 2015) még érdemes a tanulmányi tantárgyversenyeken való részvételt és az azon elért eredményeket is figyelembe venni. A megkérdezett tanulók 56\%-a nem, míg 44\%-uk részt vett tanulmányi tantárgyversenyen, közülük $16 \%$ az iskolai (helyi) szakaszon eredmény nélkül / eredménnyel, míg 20,4\% a megyei és 7,6 \% az országos/nemzetközi szakaszon eredmény nélkül / eredménnyel rendelkezik. Szektorközi összehasonlításban szignifikáns eltérést találtunk $(p=0,000)$, míg a nem felekezeti tanulók 49,3\%-a vett részt tantárgyversenyen, addig a felekezeti iskolákból mindössze 32,1\%. Az alacsony mérési szintü kategoriális változót standardizált értékükkel vontuk be az eredményességindexbe, amely ezáltal eleget tett a feltételnek.

$\mathrm{A} z$ így létrejött folytonos változót szektoron belül (felekezeti és nem felekezeti) kvartilisekre bontottuk, és arra voltunk kíváncsiak, hogy kik kerülnek az egyes negyedekre. A külön-külön megvizsgált mutatók alapján azt vártuk, hogy a bemeneti objektív típusú eredményesség felső negyedébe (4. negyed) a nem felekezeti szektort választó tanulók kerüljenek, mely feltételezésünk be is igazolódott. A lenti ábrán azt látjuk,

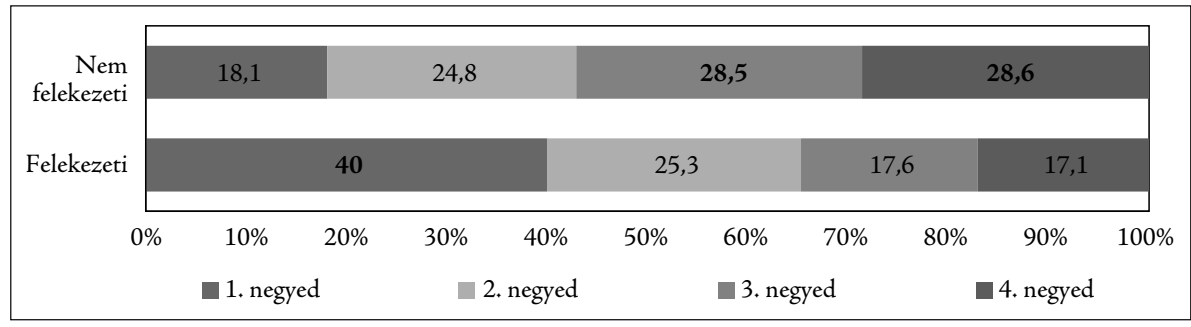

1. ábra: Objektív (kvantitatív) eredményességindex egyes negyedeibe kerülők aránya szektorközi összehasonlításban (sorszázalék, $N=1064$ ).

Forrás: egyéni számítás. Szignifikáns a Chi-négyzet próba alapján $\left(\chi^{2}=75,586 ; \mathrm{d} f=3, p=0,000\right)$. Megjegyzés: A vastagon szedett értékek arra utalnak, hogy a táblázat azon cellájába jóval többen kerültek, mint amennyi véletlen elrendeződés esetén várható lett volna (Adj. Stand. Res.: $\geq 2,0$ ) 
hogy a 3. negyedbe a nem felekezeti iskolát választó tanulók 28,5\%-a, míg a 4. negyedbe a 28,6\%-a került. Ezzel szemben a felekezeti iskolát választó tanulók nagysúlyban az alsó (1. negyedbe) szférába kerültek (40\%), így szignifikáns eltérést találunk $(p=0,000)$ a két szektorba jelentkező tanulók bemeneti tanulmányi eredményessége között. Mindez a nem felekezeti szektor (elméleti gimnáziumok) erősen szelekciós mechanizmusával magyarázható.

\section{Szubjektív (kvalitativ) típusú eredményesség}

A hazai eredményességkutatók közül néhányan az eredményesség kézzel fogható, mérhető, objektív dimenziói mellett annak szubjektív dimenzióit is bevonják a diskurzusba (Pusztai 2009, 2015; Szemerszki 2015; Bander-Galántai 2015 stb.). A kutatásunkban az eredményesség szubjektív dimenzióját a tanulóknak az iskolába járással, a tanulással, a jó jegyek szerzésével, a továbbtanulással, valamint a tanórákon való odafigyeléssel kapcsolatos attitüdjével, helyzetértékelésével mértük. A magas fokú lemorzsolódás kapcsán is lényeges a tanuló iskolába járással kapcsolatos viszonyának a feltérképezése, mely szintén az adott oktatási intézmény eredményességéröl nyújt képet (Szemerszki 2015). Továbbá a tanulás fontossága mint érték, amelyet a tanuló önmagában kialakít és tudatosít, szintén lényeges eleme az eredményességnek, hisz az itt szisztematikus tanulással mint rendszeres munkával szerzett tudásrendszert és kompetenciát élete további szakaszában is hasznosíthatja (Pusztai 2015). A tanulási motivációt a felsőfokú továbbtanulás ténye is előmozdíthatja. Nyilván itt még az aspiráció fázisáról beszélhetünk, főképp a 9. osztályos tanulók esetében, ebből adódóan a jövőbeli tervekre kérdeztünk rá. A 11. évfolyamos tanulók esetében viszont a sikeres felsőfokú továbbtanuláshoz már elengedhetetlen az adott egyetemi szakra történő tudatos készülés.

1. táblázat: Szubjektív helyzetértékelés szektorközi összehasonlításban (átlag, $N=1064$ )

\begin{tabular}{|c|c|c|c|c|c|c|c|c|c|c|}
\hline & \multicolumn{2}{|c|}{ Iskolába járás } & \multicolumn{2}{|c|}{ Tanulás } & \multicolumn{2}{|c|}{$\begin{array}{l}\text { Jó jegyek } \\
\text { szerzése }\end{array}$} & \multicolumn{2}{|c|}{$\begin{array}{l}\text { Tovább- } \\
\text { tanulás }\end{array}$} & \multicolumn{2}{|c|}{$\begin{array}{l}\text { Odafigyelés } \\
\text { az órán }\end{array}$} \\
\hline & átlag & szórás & átlag & szórás & átlag & szórás & átlag & szórás & átlag & szórás \\
\hline $\begin{array}{l}\text { Nem } \\
\text { felekezeti }\end{array}$ & 3,97 & 0,90 & 4,05 & 0,79 & 3,38 & 1,03 & 4,43 & 0,77 & 3,72 & 0,90 \\
\hline Felekezeti & 4,06 & 0,86 & 3,97 & 0,88 & 3,61 & 1,01 & 4,15 & 0,98 & 3,69 & 0,90 \\
\hline
\end{tabular}

Forrás: egyéni számítás, varianciaanalízissel ellenőrizve.

Megjegyzés: 1 - egyáltalán nem fontos..,; 5 - nagyon fontos. A vastagon szedett értékek szignifikáns eltérést jelölnek $(p=0,000)$.

A tanulók iskolai tevékenységekkel történő szubjektív helyzetértékelésében szektorközi összehasonlításban azt látjuk, hogy a felekezeti iskolát választó tanulók számára az iskolába járás és a jó jegyek szerzése fontosabb, mint a nem felekezetis tanulótársaiké, szignifikáns eltérést $(p=0,000)$ csak utóbbi esetében találtunk. Míg a tanulás, továbbtanulás ténye a nem felekezetis diákok számára fontosabbak, szignifikáns eltérést $(p=$ 0,000) itt is csak az utóbbi esetében találtunk. A felsőfokú továbbtanulás aspirációit még a szubjektív helyzetértékeléshez számítjuk, a tulajdonképpeni továbbtanulási arány már 
az objektív mutatók közé számít. A továbbiakban a fent nevesített változókból átlagolással egy indexet hoztunk létre, megvizsgálva a változók közötti korrelációt, amely közepes pozitív kapcsolatot tételez a változók között $(r=0,353-0,511)$.

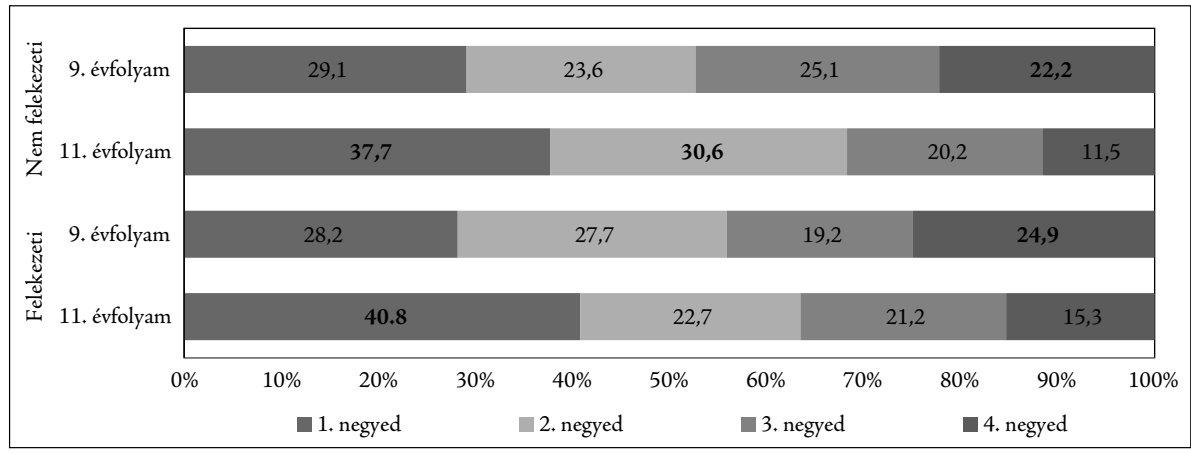

2. ábra: Szubjektív (kvalitatív) eredményességindex egyes negyedeibe kerülők aránya szektorközi és évfolyamközi összehasonlításban (sorszázalék, $N=1064$ )

Forrás: egyéni számítás. Szignifikáns a Chi-négyzet próba alapján $\left(\chi^{2}=28,480 ; \mathrm{d} f=3, p=0,000\right)$. Megjegyzés: A vastagon szedett értékek arra utalnak, hogy a táblázat azon cellájába jóval többen kerültek, mint amennyi véletlen elrendeződés esetén várható lett volna (Adj. Stand. Res.: $\geq 2,0$ )

Az objektív típusú eredményességindexhez hasonlóan itt is kvartilisekre bontottuk a létrehozott folytonos változót, és azt vizsgáltuk, hogy mely tanulói csoport kerül az index egyes negyedeibe. Az objektív típusú eredményességindexhez képest azt látjuk, hogy szektorközi összehasonlításban nincs szignifikáns eltérés a két szektor tanulóinak szubjektív eredményességindexe között. Szignifikáns eltérést évfolyamközi összehasonlításban találtunk $(p=0,000)$, és az objektív eredményességindexszel ellentétben, ahol a 11. évfolyam tanulói kerültek nagy százalékban a felső negyedbe, itt épp ellenkező elöjellel, a 9. évfolyam tanulói kerültek oda (23\%), míg a 11. évfolyam tanulói nagyrészt (38,7\%) az alsó negyedben helyezkednek el.

\section{A tanulói eredményességre ható magyarázó változók}

A továbbiakban arra keressük a választ, hogy a fentebb bemutatott objektív (kvantitatív) és szubjektív (kvalitatív) típusú eredményességre milyen tényezők vannak hatással, és mindez hogyan nyilvánul meg szektorközi összehasonlításban. Ezt lineáris regresszióelemzéssel (stepwise) vizsgáltuk. Tanulmányunkban a tanulók családi hátterének hatását, korábbi iskolai eredményeit, valamint néhány demográfiai jellemző hatóerejét vizsgáljuk meg az eredményesség két dimenziójára vonatkozóan. Létrehoztuk a család kulturálistőke-indexét, amelybe a szülők iskolai végzettségét, az otthon található könyvek számát, valamint az olvasási szokásokat vontuk be. A tanulók családjának objektív anyagi helyzetét mérő tíz változóból standardizált áltag számítással egy ún. „vagyon-indexet” hoztunk létre. A tanulók családjának szubjektív anyagi helyzetét értékelő tényezőt külön is megvizsgáltuk, majd bevontuk a család anyagiháttér-mutatójába, tudva, hogy a két index közti korreláció nagyon magas $(r=0,98)$. Mindezt a tanuló neme és lakóhelye változókkal egészítettük ki. Ez utóbbinak nincs szignifikáns hatása az eredményességre. 
2. táblázat: Magyarázó változók hatása a tanulók eredményességére (béta-súly / standardizált regressziós együttható; $N=1064$ )

\begin{tabular}{|c|c|c|c|c|}
\hline & \multicolumn{2}{|c|}{$\begin{array}{l}\text { Objektív (kvantitatív) } \\
\text { eredményesség }\end{array}$} & \multicolumn{2}{|c|}{$\begin{array}{l}\text { Szubjektív (kvalitatív) } \\
\text { eredményesség }\end{array}$} \\
\hline & Beta & Szign, szint & Beta & Szign. szint \\
\hline Neme (1 - fiú; 2 - lány) & 0,210 & 0,000 & 0,204 & 0,000 \\
\hline Általános iskolai eredménye & 0,280 & 0,000 & & \\
\hline Család kulturális tőkéje & 0,103 & 0,001 & & \\
\hline Család objektív anyagi helyzete & $-0,064$ & 0,026 & & \\
\hline Család szubjektív anyagi helyzete & & & 0,070 & 0,023 \\
\hline$R^{2}$ & \multicolumn{2}{|c|}{0,141} & \multicolumn{2}{|c|}{0,044} \\
\hline
\end{tabular}

Forrás: egyéni számítás, lineáris regresszióval ellenőrizve

A magyarázó modellbe bevont öt tényező az objektív eredményességindex esetében 14\%-os, míg a szubjektív eredményességindex esetében csupán 4\%-os magyarázóerővel bír. A kétféle eredményesség esetében a magyarázó változók hatásainak mértéke eltérő: az objektív eredményességre a legjelentősebb hatása az általános iskolai eredménynek van, amelyet a tanuló neme és a család kulturális tőkéje követ. A szubjektív eredményességre csak a tanuló neme van pozitív hatással. Az objektív eredményességre elhanyagolható hatást gyakorol a család objektív anyagi helyzete, míg a szubjektív anyagi helyzete nem is fejt ki szignifikáns hatást, a szubjektív eredményességre pedig a család szubjektív anyagi helyzetének van hatása.

Amint az várható volt, a tanulói objektív eredményességre a megelőző általános iskolai eredménynek van a legnagyobb hatása, viszont az a szubjektív eredményességre nem fejt ki szignifikáns hatást. Fentebb jeleztük, hogy a középiskolai felvételi átlagba számít a tanuló általános iskolai eredménye, márpedig ez a megcélzott, szándékolt iskolába, profilra és szakra való bejutás előfeltételét is jelenti. A mintánkba bevont gimnáziumok nemi megoszlás tekintetében 63\%-a lány, míg a szakközépiskolák esetében ellentétes előjellel 39\%-a lány (Gergely 2015), mely tény a fiúk önszelekciós mechanizmusával magyaráz-

3. táblázat: Az objektív (kvantitatív) típusú eredményességre ható tényezők szektorközi összehasonlításban (béta-súly / standardizált regressziós együttható; $N=1064$ )

\begin{tabular}{lcccccc}
\hline & \multicolumn{2}{c}{ Nem felekezeti } & & \multicolumn{2}{c}{ Felekezeti } \\
\cline { 2 - 3 } \cline { 5 - 6 } & Beta & Szign. szint & & Beta & Szign. szint \\
\hline Neme (1 - fiú; 2 - lány) & 0,191 & 0,000 & & 0,099 & 0,000 \\
Általános iskolai eredménye & 0,225 & 0,000 & & 0,088 & 0,000 \\
Család kulturális tőkéje & 0,071 & 0,043 & & 0,075 & 0,004 \\
Család objektív anyagi helyzete & & & & 0,117 & 0,028 \\
\hline$R^{2}$ & \multicolumn{2}{c}{0,092} & & \multicolumn{2}{c}{0,152} \\
\hline
\end{tabular}

Forrás: egyéni számítás, lineáris regresszióval ellenőrizve 
ható. A mintánkon belül a lányok szignifikánsan magasabb objektív és szubjektív eredményesség-indexértékkel rendelkeznek, mint a fiúk. Tehát azt látjuk, hogy az elméleti gimnáziumok, ahová magasabb átlageredménnyel lehet bejutni, a lányoknak kedveznek, ugyanakkor gimnáziumon belül is a lányok rendelkeznek magasabb eredményességi mutatóval.

Az objektív eredményességre ható tényezőket szektorközi összehasonlításban is megvizsgáltuk. A magyarázó modellbe bevont négy tényező a nem felekezeti szektor esetében 9\%-os, míg a felekezeti szektor esetében 15\%-os magyarázóerővel bír. A nem felekezeti szektor számára a legerősebb magyarázóerővel a tanulók általános iskolai eredménye bír, mely hatással van a felekezeti iskolába jelentkező tanulók tanulmányi eredményességére is, de alacsonyabb mértékben. Mindez alátámasztja azt a tényt is, hogy a nem felekezeti szektorba jelentkező tanulók számára magasabb bemeneti eredmények szükségesek. A család kulturális tőkéjének objektív típusú eredményességre gyakorolt hatása mindkét iskolatípusban hasonló mértékben jelen van. Továbbá a család objektív anyagi helyzete is hatással van a felekezeti szektorhoz tartozó tanulók eredményességére.

Lényeges továbbá azt is kiemelnünk, hogy a szülők kulturális tőkéjének hatása az általános iskolai eredményre is hat, hisz az 5-8. átlagosztályzatot 10\%-ban magyarázza, melyből adódóan az általános iskolai eredmény hatása a családi háttér hatását is tartalmazza. Amennyiben csak a szülők legmagasabb iskolai végzettségét vizsgáljuk, akkor az anya iskolázottságának mutatkozik nagyobb hatása a tanulók objektív és szubjektív eredményességére egyaránt. Ráadásul az általános iskolai eredménynek, valamint az egységes országos mérés eredményeinek a család kulturális tőkéjétől függetlenül is nagy szerepe van, mely tényező elsődleges szerepet (korlátozó funkciót) tölt be a tanulók középiskolaválasztása körüli döntés meghozatalában.

\section{Összegzés}

Tanulmányunkban a középiskolába jelentkező tanulók bemeneti eredményességét vizsgáltuk, amelynek árnyaltabb elemzésére az eredményesség két - objektív (kvantitatív) és szubjektív (kvalitatív) - dimenzióját konstruáltuk meg. Az egyikbe olyan mutatókat vontunk be, mint az egységes országos mérés eredményei, az első félévi kiemelt tantárgyak átlageredményei stb., míg a másik a tanulók tanulással, továbbtanulással, iskolába járással stb. kapcsolatos attitüdjeit tömöríti magába. Az így létrehozott indexeket kvartilisekre bontottuk, és azt vizsgáltuk, hogy mely tanulói csoport mely negyedbe tartozik. Az öszszefüggéseket szektorközi bontásban vizsgáltuk, és az objektív típusú eredményesség kapcsán szignifikáns eltérést találtunk a képzési típusok szerint: a nem felekezeti iskolát választó tanulók az objektív eredményességindex felső negyedébe tartoznak. A szubjektív eredményességindex esetében nem találtunk szignifikáns eltérést.

Lényegesnek találtuk a szubjektív helyzetértékelés vizsgálatát is, hisz például a tanulás iránti elköteleződés nem feltétlenül azonnal és közvetlen módon nyilvánul meg a mérhető eredményesség kapcsán, viszont annak tudatosítása, hogy a tanulás hasznos, kihatással lehet a tanuló későbbi életpályájára. Majd azt kutattuk, hogy mely magyarázó tényezők hatása járul hozzá a kéttípusú tanulói eredményességhez. Az eredményekből azt találtuk, hogy elsősorban a korábbi általános iskolai teljesítmények, valamint a szülői kulturális tőkének van a legnagyobb pozitív hatása, amely szektorközi összehasonlításban eltérést mutatott. 
Összességében véve azt tapasztaltuk, hogy a nem felekezeti szektor erős szelekciós mechanizmusa révén egy homogén tanulói közeget verbuvál. További mélyrehatóbb elemzés szükséges ahhoz, hogy még árnyaltabb képet nyerhessünk a tanulók középiskolai eredményességdimenzióinak háttértényezőiről.

\section{IRODALOM}

BACskaI K. (2015) Iskolák a társadalom peremén. Alacsony státusú diákokat tanitó eredményes tanárok. Szeged, Belvedere Meridionale.

BALÁzsi I. (2016) A hozzáadottérték-modellek alkalmazása a tanulói teljesítménymérésekben. Magyar Pedagógia, Vol. 116. No. 1. pp. 3-23.

Bander K. \& Galántai J. (2015) Az eredményesség dimenziói és háttértényezői intézményi szemmel. In: Szemerszki M. (ed.) Eredményesség az oktatásban. Dimenziók és megközelitések. Budapest, OFI. pp. 92-129.

Gergely E. (2015) Az erdélyi magyar szakiskolások társadalmi háttere. In: Pletr R. (ed.) Anyanyelvoktatás. A magyar tannyelvü szakközépiskolai oktatás belyzete. Kolozsvár, Ábel Kiadó. pp. 97-111.

Horn D. (2015) Az iskolai hozzáadott érték mérése. In: SzéLl K. (ed.) Mit mér a müszer? A tanulói teljesitménymérések alkalmazhatóságáról. Budapest, OFI. pp. 63-90.

Lannert J. (2004) Hatékonyság, eredményesség és méltányosság. Új Pedagógiai Szemle, Vol. 54. No. 12. pp. 3-15.

Morvai L. (2018) Ora et labora? Egyházi középiskolások eredményessége a 2010 utáni szektorbövülést követöen. Debrecen, Debreceni Egyetem (PhD-disszertáció).

Pusztai G. (2004) Iskola és közösség. Felekezeti középiskolások az ezredfordulón. Budapest, Gondolat.

Pusztai G. (2009) A társadalmi töke és az iskola. Budapest, Új Mandátum Kiadó.

Pusztai G. (2015) Az eredményesség kapcsolati beágyazottsági háttere. In: Imre A. (ed.) Eredményesség és társadalmi beágyazottság. Budapest, OFI. pp. 23-36.

SzéLl K. (2015) Mit mér a müszer? A tanulói teljesitménymérések alkalmazhatóságáról. Budapest, OFI.

Szemerszki M. (2015) A tanulói eredményesség dimenziói és háttértényezői. In: Uő. (ed.) Eredményesség az oktatásban. Dimenziók és megközelitések. Budapest, OFI. pp. 52-91.

A cikk a Creative Commons Attribution 4.0 International License (https://creativecommons.org/licenses/ by/4.0/) feltételei szerint publikált Open Access közlemény, melynek szellemében a cikk bármilyen médiumban szabadon felhasználható, megosztható és újraközölhető, feltéve, hogy az eredeti szerző és a közlés helye, illetve a CC License linkje és az esetlegesen végrehajtott módosítások feltüntetésre kerülnek. (SID_1) 